\title{
CRATER DEPOSITS OF THE MWADUI KIMBERLITE
}

\author{
Johann Stiefenhofer ${ }^{1}$ and Darrell Farrow ${ }^{2}$ \\ ${ }^{1}$ De Beers Geoscience Centre, South Africa; ${ }^{2}$ De Beers Corporate Headquarters, South Africa
}

\section{INTRODUCTION}

The Mwadui kimberlite was discovered in 1940 by Dr J.T. Williamson and is the largest primary deposit of its kind in the world ever to be mined, measuring some 146 ha at surface. The kimberlite has intruded basement granites that can be divided into two distinct types, viz. a younger porphyritic variety and an older gneissic suite.

The currently exposed deposits represent an almost perfectly preserved example of kimberlite crater-fill. This Cretaceous-aged kimberlite, situated approximately $161 \mathrm{~km}$ south of Lake Victoria in the Shinyanga district of Tanzania, has been mined continuously as an open pit operation since its discovery. The kimberlite is characterised by a low average recovery grade ranging between 10.2-10.7 cpht and a revenue per carat of US\$100-106 (De Beers annual reports, 1999, 2000). The mine contains an inferred resource of $114 \mathrm{Mt}$ of kimberlite, containing some 6.5 million carats of diamonds at an average grade of $5.7 \mathrm{cpht}$.

\section{GEOLOGY OF THE MWADUI KIMBERLITE}

The geology of the Mwadui kimberlite pipe comprises five major units, viz. the Shale Basin, the Bouma Facies, Granite Breccias (subdivided into two units), other Resedimented Volcaniclastic Kimberlite deposits (RVK) and probable primary pyroclastic kimberlite (PK). The PK can be further subdivided into distinct units. These subdivisions represent a summary of the geological studies by previous geologists from 1956 to the present day (Tremblay, 1956; Edwards and Howkins, 1966; Gobba and Rupia, unpubl.; Skilling, 1998), but with modification for current-day mining purposes, as well as new data obtained by the authors during 19992002. A three-dimensional GEMCOM ${ }^{\mathrm{TM}}$ model has been constructed to encompass all of these features. Figure 1 illustrates the spatial relationship of the various units with respect to each other. The major geological units are summarized in Table 1.
The bulk of all previous work, with the exception of that of Edwards and Howkins (1966), has focused on the resedimented deposits in the upper part of the crater due to mining activity and resultant exposure. Recent deep drilling has however allowed a much more detailed examination of the deposits found in the lower crater.

Upward-fining units ranging in thickness from a few centimeters through several meters up to $30 \mathrm{~m}$ or more dominate the pyroclastic package. Changes in granite content, as well as changes in granite clast size (Figure 2) largely define thicker bedding sequences. A single unit from its base upwards is typically defined by an abrupt transition, characterized by a notable increase in granite abundance and/or size, followed by a gradual decrease in these parameters upwards, until the base of the following unit is encountered. These units may appear superficially massive on a localized (handspecimen) scale, but are invariably diffusely stratified over a larger distance. Thinly bedded units of several centimeters are typically defined by concentrations of angular granite clasts, as well as less frequent lapillisized magmaclasts. The bulk of these deposits can be classified as lapilli tuffs. The macroscopic layering is also observable on a microscopic scale in the form of variations in modal lithic abundance, where changes occur from clast- to matrix-supported and back again. Broad zones are also defined within these deposits by the alternating presence or absence of cryptocrystalline phlogopite in the juvenile lapilli. The bulk of the ejecta within the pyroclastic package appears to have originated from one event. Some variation must however have occurred, judging by the variation in thickness of units in various parts of the crater, as well as the presence of distinct darker juvenile-rich horizons, characterized by the almost total absence of granite (Figure 3). The latter further enhances the layered nature of the deposits imparted by the variation in granite content.

The appearance of the pyroclastic deposits at Mwadui is such that they cannot readily be attributed to any single volcanic process. These rocks appear to represent complex hybrid deposits, formed as a result of interplay between different volcanic processes in the eruption column. Pyroclastic fall processes have 


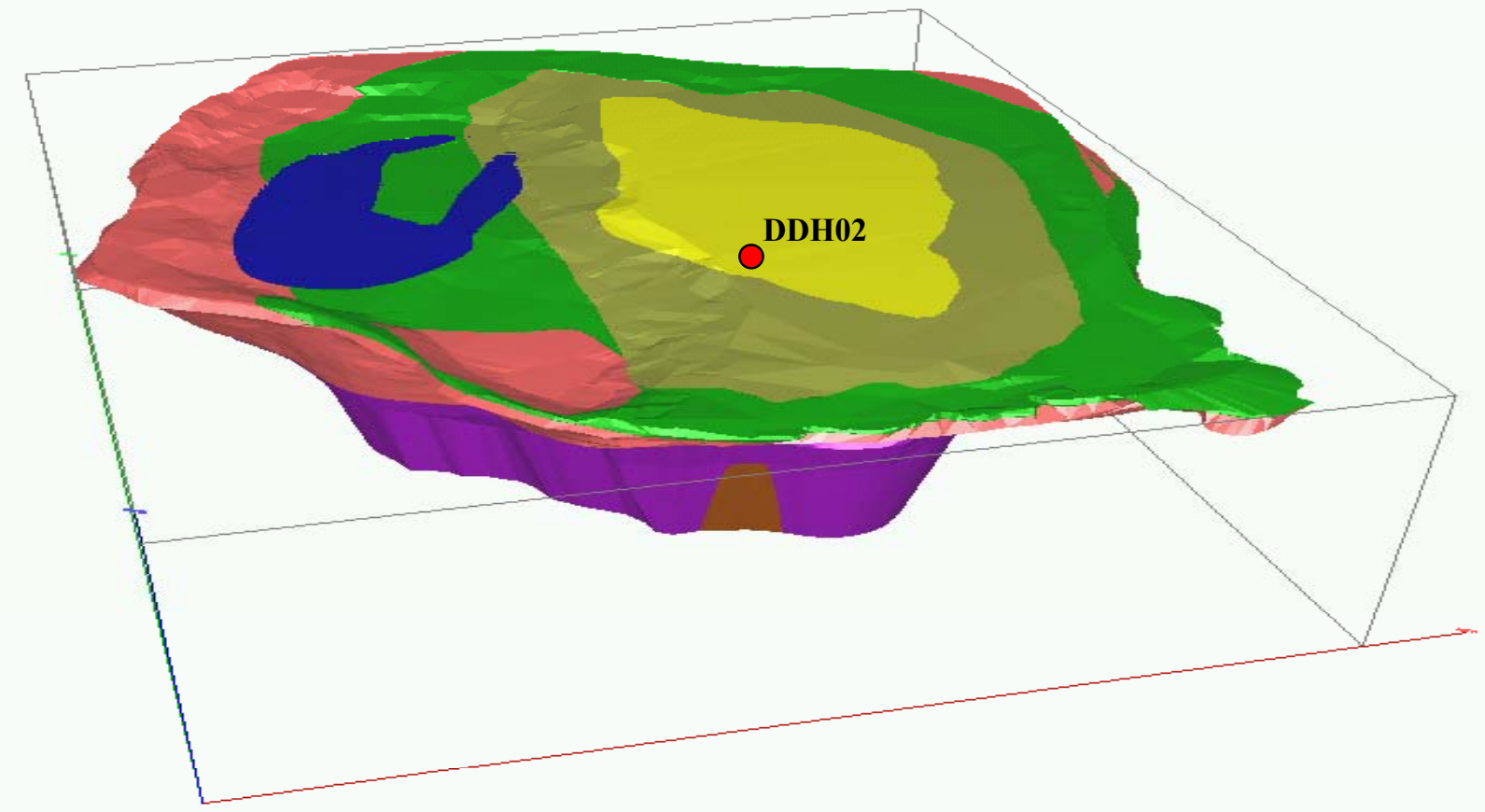

Figure 1: Spatial relationship of the various geological units at current surface with pit outlines and the extent of mining operations during 2001 shown. The pipe is approximately $1.5 \times 1.2 \mathrm{~km}$ in size (Edwards and Howkins, 1966) and is viewed looking slightly east of north. The crater is at least $684 \mathrm{~m}$ in depth, but the base of this image only extends to about two-thirds of that distance. The various rock types are: yellow (Shale Basin), olive-green (Bouma Facies), green (Resedimented Volcaniclastic kimberlite), red (Granite Breccia), blue (Breccia and Volcaniclastic Kimberlite, purple (Pyroclastic Kimberlite). The blue pincer-shaped structure in the west of the crater defines a zone of increasing granite content in the RVK. The Shale Basin is virtually untouched by mining due to the low grade in this deposit.

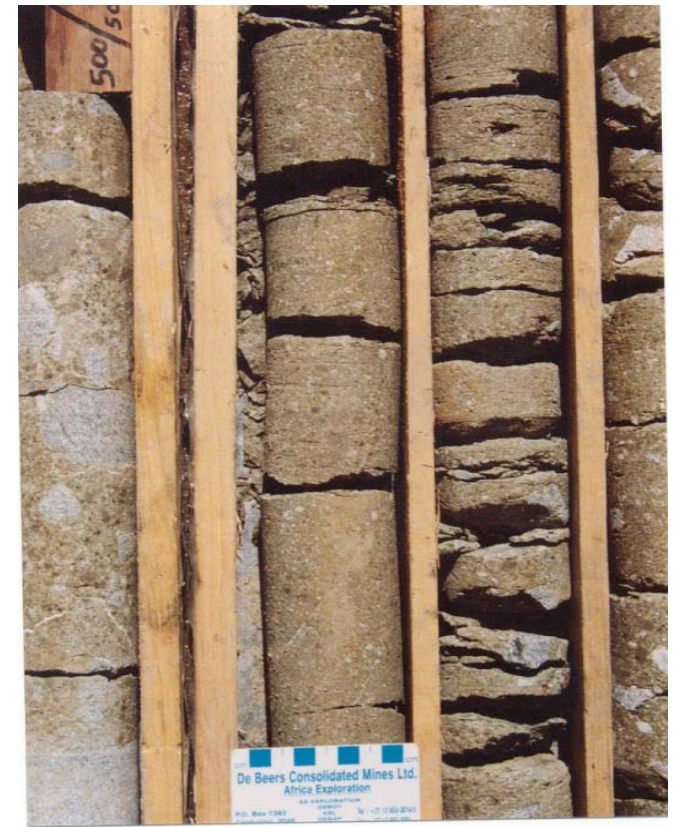

Figure 2: Bedding at $500.5 \mathrm{~m}$, drill hole DDH02. Top of the hole is to the left. Note layering defined by granite abundance.

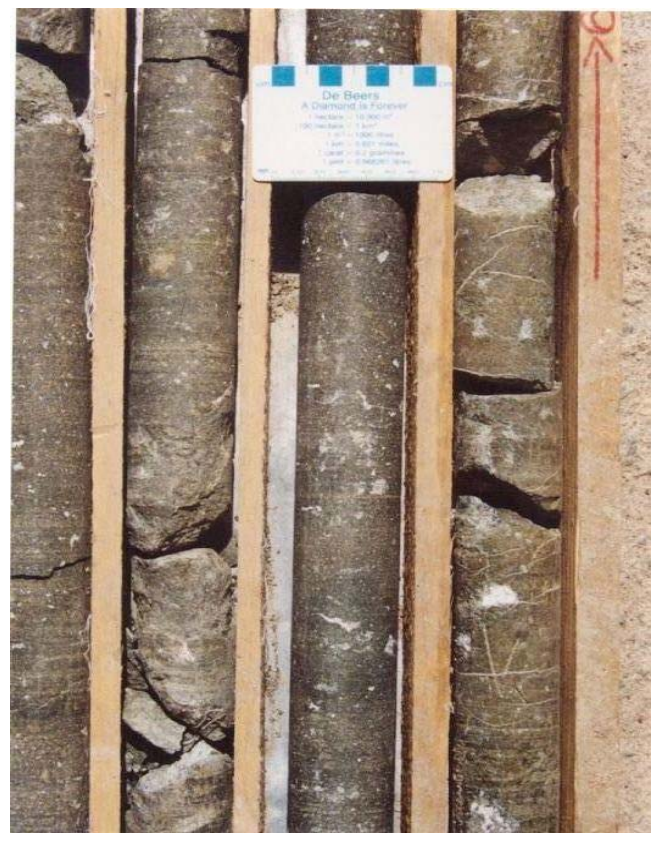

Figure 3: Juvenile-rich lapilli tuff at $667 \mathrm{~m}$, drill hole DDH02. Top of the hole is to the left. Note the paucity of granite. Small white areas are carbonate. 
Table 1: Summary of the major geological units of the Mwadui kimberlite. The geology of the crater deposits exhibits a high degree of complexity and had to be simplified for mining purposes. This applies particularly to the Bouma facies, RVK and Granite Breccia units.

\begin{tabular}{|c|c|}
\hline Unit/facies & Comments \\
\hline Yellow shales & $\begin{array}{l}\text { "Shale basin" The final phase of crater lake in-fill by suspension sedimentation and distal } \\
\text { turbidites (Skilling, 1998). These silts and muds were deposited under relatively oxidizing } \\
\text { conditions and do not contain any plant material (although imprints do occur), carbonaceous } \\
\text { layers, or pyrite which serves to distinguish it from the Bouma Facies below. Due to the } \\
\text { extremely fine grain size this unit is not of economic significance and is removed as waste } \\
\text { during mining. Syn- and post-depositional mass-flow deposits have disrupted the shale deposits } \\
\text { in places. }\end{array}$ \\
\hline Bouma facies & $\begin{array}{l}\text { Turbidite deposits containing graded bedding, ripple laminations and foresets (Skilling, 1998). } \\
\text { Three inter-bedded carbonaceous mud layers are present. Abundant recognisable plant remains } \\
\text { occur in the upper two. These deposits comprise the dominant part of the central depositional } \\
\text { basin, although the material is often grouped with the Yellow shales and collectively referred to } \\
\text { as the Shale Basin. The transition between the Shale Basin and the Bouma facies was taken as } \\
\text { the entry of alternating shale and grit-sized units. May grade directly into granite breccia in } \\
\text { places. }\end{array}$ \\
\hline RVK & $\begin{array}{l}\text { The western part of the crater contains abundant resedimented volcaniclastic kimberlite (RVK) } \\
\text { dipping towards the east underneath/against the Bouma sequence. Dominated by density } \\
\text { modified grain-flow deposits with very low dilution and high juvenile content, hence the good } \\
\text { grades normally associated with this material. Other types of mass-flow deposits may also } \\
\text { occur, inter-bedded with granite-rich zones. Although the upper shale and Bouma deposits may } \\
\text { also be classified as resedimented in nature, Skilling (1998) identified density modified grain } \\
\text { flow as being the dominant re-sedimentation process in this package. The RVK's typically } \\
\text { contain less than } 40 \% \text { granite and the granite clasts are generally much smaller in comparison to } \\
\text { the granite breccias. These deposits contain amongst the highest diamond grades in the current } \\
\text { mine. }\end{array}$ \\
\hline $\begin{array}{l}\text { Granite } \\
\text { Breccia }\end{array}$ & $\begin{array}{l}\text { The lower mudstone horizon in the Bouma facies is followed by a substantial granite breccia } \\
\text { zone which attains a maximum thickness of } 214 \mathrm{~m} \text { near the centre of the basin (Edwards, 1970), } \\
\text { These breccias derived from sidewall collapse and subaqueous debris flows. Subdivided into } \\
\text { barren to low grade granite breccia (GB) containing } 75 \%+\text { granite and breccia with } \\
\text { volcaniclastic kimberlite layers (BVK) of moderate to good grade, depending on the matrix } \\
\text { content. The latter typically contains } 40-75 \% \text { granite. }\end{array}$ \\
\hline PK & $\begin{array}{l}\text { Start of the primary pyroclastic deposits, which are characterised by a much more homogeneous } \\
\text { appearance than those above. These deposits appear massive on a localised scale, but are in fact } \\
\text { diffusely (dominant) to well bedded in some areas and extend to at least } 684 \mathrm{~m} \text { vertical depth } \\
\text { (limit of current drill core). This material has been described by Edwards and Howkins (1966) } \\
\text { from the } 1200 \text {-ft ( } 366 \mathrm{~m}) \text { sampling tunnels and re-interpreted by the current authors during } \\
\text { recent deep drilling. The material closely resembles tuffisitic kimberlite breccia (TKB) in hand } \\
\text { specimen (after the classification of Clement and Skinner, 1985) and also contains microlitic } \\
\text { clinopyroxene in places (see text). }\end{array}$ \\
\hline
\end{tabular}


been identified but there is still some uncertainty as to the presence of possible surge and/or flow processes, overprinted by syn-eruptive resedimentation in places. It is interesting to note that very fine-grained acicular (microlitic) clinopyroxene was positively identified in a number of samples. The formation of this mineral would require relatively high temperatures. Pyroclastic flow processes can therefore not be ruled out entirely, although obvious fumarolic structures were not observed. Rare examples were found that could be interpreted as poorly developed welding or molding of juvenile lapilli.

\section{THE RELATIONSHIP BETWEEN GEOLOGICAL FACIES AND DIAMOND GRADE}

Available diamond sampling data were examined and correlated with the geology where possible. Data include sampling results from the old $120(37 \mathrm{~m}), 200$ $(61 \mathrm{~m}), 300(92 \mathrm{~m})$ and $1200 \mathrm{ft}(366 \mathrm{~m})$ sampling levels, pits sunk during historical mining operations, drill logs, as well as more recent bench mapping (Skilling, 1998). A clear relationship between diamond grade and the type of facies is evident in most instances. Studies have shown that localized enrichment of the primary diamond grade has taken place in the upper resedimented volcaniclastic deposits due to syn- and post-eruptive sedimentary in-fill processes. These enriched areas formed largely as a result of modified grain flow deposits. The posteruptive sedimentary in-fill processes have however also significantly diluted the diamond grade over large areas within the crater due to the introduction of vast amounts of shattered granite country rock. A thick band of these breccias, often inter-layered with resedimented volcaniclastic material, has been interpreted as defining the floor of the old crater immediately after final volcanic activity ceased. This zone marks the boundary between the heterogeneous diamond grades of the upper crater and the more constant grade distribution of the lower crater/pyroclastic deposits. The end of the graniterich zone marks the first appearance of a very finegrained acicular mineral identified as microlitic diopside in petrographic studies. The pyroclastic deposits rather than the surface/upper crater deposits represent the real "primary grade" of the pipe. Indeed, a number of similarities exist between the deposits in the Mwadui crater compared to e.g. the South Lobe at Orapa (Field et al., 1997).

\section{CONCLUSIONS}

The Mwadui kimberlite represents the largest diamondiferous kimberlite ever mined and is an almost perfectly preserved example of a kimberlite crater, albeit without the tuff ring. Study of this kimberlite highlighted the striking similarity between Mwadui and the Orapa kimberlite in Botswana (Field et al., 1997). Comparison has been facilitated by the high state of preservation of the crater deposits at both occurrences.

The Mwadui kimberlite illustrates vividly how secondary enrichment processes may enhance the surface and upper crater diamond grades of a kimberlite to significant levels. It is crucial to identify 1) the processes involved in the formation of these deposits, 2) the boundary between the upper crater deposits and the "unmodified" primary pyroclastic material. The latter will typically provide a more representative diamond grade estimate of the overall pipe. High diamond grades in a kimberlite are generally rather forgiving in the event of poor mine planning and waste control during mining. This is however not the case for those kimberlites with low but mineable grades, such as Mwadui, where the key to successful and cost-effective mining lies in geological knowledge, effective management of ore dilution and efficiency of ore treatment.

\section{REFERENCES}

Clement, C.R., Skinner, E.M.S., 1985. A textural-genetic classification of kimberlites. Trans. Geol. Soc. S. Afr., $88,403-409$.

Edwards, R., 1970. Geology and sampling of the Mwadui diamond mine. J. of the Mwadui Engineering Association, vol. 1, no. 2.

Edwards, C.B., Howkins, J.B., 1966. Kimberlites in Tanganyika with special reference to the Mwadui occurrence. Economic Geology, 61, 537-554.

Field, M., Gibson, J.G., Wilkes, T.A., Gababotse, J., Khutjwe, P., 1997. The Geology of the Orapa A/K1 kimberlite Botswana: Further insight into the emplacement of kimberlite pipes. In: Proceedings of the Sixth International Kimberlite Conference. Russian Geology and Geophysics, 38, 24-39.

Skilling, I., 1998. Evolution of Mwadui kimberlite crater, Tanzania: a facies model for the surface geology. 
Confidential report for De Beers and Williamson Diamonds Ltd.
Tremblay, M., 1956. Geology of the Williamson diamond Mine. Unpubl. Ph.D. thesis, McGill University.

Contact: J. Stiefenhofer, De Beers Geoscience Centre, P.O. Box 82232, Southdale 2135, South Africa, E-mail:

johan.stiefenhofer@debeersgroup.com 